\title{
Nitroxyl, the novel redox sibling of NO, suppresses cerebrovascular NADPH oxidase
}

\author{
Barbara Kemp-Harper*1, Ravina Ravi ${ }^{1}$, Michelle Bullen ${ }^{1}$, Rebecca Ritchie ${ }^{2}$, \\ Christopher Sobey ${ }^{1}$ and Alyson Miller ${ }^{1}$
} \author{
Diabetes Institute, Melbourne, Vic 8008, Australia \\ Email: Barbara Kemp-Harper* - barbara.kemp@med.monash.edu.au \\ * Corresponding author \\ from 4th International Conference of cGMP Generators, Effectors and Therapeutic Implications \\ Regensburg, Germany. 19-21 June 2009 \\ Published: II August 2009 \\ BMC Pharmacology 2009, 9(Suppl I):P3 I doi:I0.||86/|47|-22I0-9-SI-P3 I
}

Address: ${ }^{1}$ Department of Pharmacology, Monash University, Clayton, Vic 3800, Australia and ${ }^{2}$ Heart Failure Pharmacology, Baker IDI Heart \&

This abstract is available from: http://www.biomedcentral.com/|47|-22/0/9/SI/P3 I

(c) 2009 Kemp-Harper et al; licensee BioMed Central Ltd.

\section{Background}

Nitroxyl (HNO), the reduced and protonated congener of nitric oxide (NO), is emerging as a novel entity with distinct pharmacology and therapeutic advantages over NO• [1]. Importantly, HNO has vasoprotective actions with the potential to serve as an antioxidant. Here we explored the ability of HNO to modulate cerebrovascular NADPH oxidase activity, a major source of superoxide $\left(\mathrm{O}_{2}^{-}\right)$in the vasculature.

\section{Materials and methods}

Intracranial (pooled middle cerebral and basilar) and extracranial (carotid) cerebral arteries from male C57BL/ $6 \mathrm{~J}$ mice were treated with angiotensin II (10 $\mathrm{nM})$ acutely (30 min) and chronically $(24 \mathrm{~h})$, respectively, in the absence and presence of the HNO donor, Angeli's salt (AS). NADPH $(100 \mu \mathrm{M})$-stimulated $\mathrm{O}_{2}$ - production was then measured using lucigenin $(5 \mu \mathrm{M})$-enhanced chemiluminescence.

\section{Results}

AS $(1 \mu \mathrm{M})$ did not scavenge $\mathrm{O}_{2}{ }^{-}$generated in a cell free xanthine $(100 \mu \mathrm{M}) /$ xanthine oxidase $(0.05 \mathrm{U} / \mathrm{ml})$ activity assay (control: $447.9 \pm 90.8$; AS 507.1 \pm 113.3 counts, $\mathrm{n}=$ 4). In contrast, acute and chronic treatment with AS (0.01-1 $\mu \mathrm{M})$ caused a concentration-dependent decrease in NADPH oxidase-derived $\mathrm{O}_{2}$ - production by intracranial and extracranial cerebral arteries, respectively (carotid
$0.59 \pm 0.05 ;$ AS $0.1 \mu \mathrm{M} 0.33 \pm 0.08$; AS $1 \mu \mathrm{M} 0.16 \pm 0.03$ $10^{3}$ counts $/ \mathrm{s} / \mathrm{mg}, \mathrm{P}<0.05, \mathrm{n}=8$ ). The effects of AS were reversed by the HNO scavenger, L-cysteine ( $3 \mathrm{mM})$ but unchanged in the presence of the $\mathrm{NO}{ }^{\bullet}$ scavenger carboxyPTIO $(200 \mu \mathrm{M})$ and sGC inhibitor, ODQ $(10 \mu \mathrm{M})$.

\section{Conclusion}

HNO suppresses vascular NADPH-oxidase activity both acutely and chronically, possibly via a cGMP-independent mechanism. Such antioxidant actions of HNO may confer therapeutic advantages in the treatment of cerebrovascular disorders.

\section{References}

I. Irvine JC, Ritchie RH, Favaloro JL, Andrews KL, Widdop RE, KempHarper BK: Nitroxyl (HNO): the Cinderella of the nitric oxide story. Trends Pharmacol Sci 2008, 29:60I-8. 